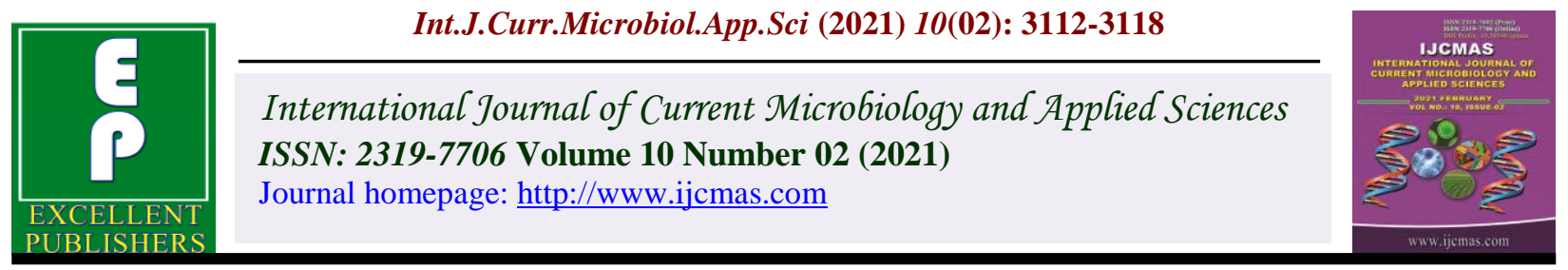

Original Research Article

https://doi.org/10.20546/ijcmas.2021.1002.340

\title{
Effect of Different Levels of Sulphur and Magnesium on Growth, Yield and Quality of Onion
}

\author{
Dubey Bhashkar* and Singh Devi \\ Department of Horticulture, Sam Higginbottom University of Agriculture, Technology and \\ Sciences, Prayagraj-211007, India \\ *Corresponding author
}

\section{A B S T R A C T}

Keywords

Sulphur,

Magnesium

Article Info

Accepted:

22 January 2021

Available Online:

10 February 2021
The present experiment was carried out during 2019-20 at Horticulture Farm of Department of Horticulture, SHUATS, Prayagraj. The experiment was conducted in Randomized Block Design (RBD), with 10+1 treatments, replicated thrice the treatments were $\mathrm{T}_{1}$ Control, $\mathrm{T}_{2} \mathrm{RDF}(100 \%), \mathrm{T}_{3}$ Sulphur@2\%, $\mathrm{T}_{4}$ Sulphur @ 4\%, $\mathrm{T}_{5}$ Sulphur @ 6\%, $\mathrm{T}_{6}$ Sulphur @ 8\%, $\mathrm{T}_{7}$ Magnesium@2\%, $\mathrm{T}_{8}$ Magnesium@ 4\%, T9 Magnesium@6\%, $\mathrm{T}_{10}$ Magnesium@8\%. From the present investigation it is found that treatment $\mathrm{T}_{10}$ Magnesium@8\% was found superior in respect of the parameters Plant height $(\mathrm{cm})$, Number of Leaves per plant, Fresh weight of bulb per plant (g), Neck thickness $(\mathrm{mm})$, Equatorial diameter of bulb $(\mathrm{cm})$, Polar diameter of bulb (cm), Bulb yield (q/ha), Total soluble solid ( ${ }^{\circ}$ Brix).

\section{Introduction}

Onion (Allium cepa L.) belongs to family Alliaceae is an established commercial bulbous crop and is one of the most common and indispensable vegetable cum condiment crop grown and consumed widely across the world. It is used as salad or cooked in various ways in all curries, fried, boiled or baked. It has very good medicinal value. Nutritive value of onion varies from variety to variety. Small sized onions are more nutritive than big ones. Its major value is in its flavor. Onion ranks medium in calorific value. The factual demand of onions within the country and for the export has made it essential to supply onions round the year either form fresh harvest or from stocks. Onion is a native of Asia. In India onion is mainly cultivated in the states Maharashtra, Bihar, Karnataka, Gujrat, Andhra Pradesh, Uttar Pradesh, Orissa and Madhya Pradesh. Onion is an export oriented crop earning valuable foreign exchange for the country. The onion export is done mainly to Malaysia, Singapore, Bangladesh, Nepal, Srilanka, Mauritius, Philippines, Indonesia, 
gulf countries and Pakistan. In India onion occupies 882 thousand hectare area with a production of 18736 thousand MT and average productivity is $21.2 \mathrm{MT} /$ hectare (NHB 2014). It ${ }^{\mathrm{ee}} \mathrm{s}$ acreage in Madhya Pradesh is 117.3 Thousand hectare area with a production of 2826.0 Thousand MT and average productivity is $24.1 \mathrm{MT} /$ hectare

Magnesium (Mg), similarly as the other metallic nutrients, is contained in soil in 3 fractions: exchangeable, inexchangeable and water soluble (1). The inexchangeable fraction is composed of magnesium contained in primary and secondary minerals, including those of different hydration rates (2). In turn, the exchangeable fraction of this nutrient typically accounts for approx. 5\% total magnesium content in soil and from 4 to $20 \%$ cation exchange capacity of soil. Magnesium is an important and essential macronutrient for the proper development and functioning of living organisms. It participates in the regulation of many biochemical processes, first of all being involved in the appropriate functioning of the brain in animals and humans. It is also a component of systemic fluids and bones. In case of plants magnesium (from 15 to $30 \%$ its total contents) is bound in chlorophyll molecules $(3,4)$. It is estimated that magnesium in $75 \div 80 \%$ serves the function of a co-factor in many enzymatic processes, connected e.g. with phosphorylation, dephosphorylation, as well as hydrolysis of different compounds, and what is more it stabilizes the structure of different nucleotides (1). Magnesium requirement of plants to a considerable degree depends on the pool of available forms of this nutrient in the soil. It usually amounts to 1 to over $20 \mathrm{mg} \mathrm{Mg} \cdot 100 \mathrm{~g}$ soil. Magnesium is absorbed by plants in the form of the $\mathrm{Mg} 2+$ cation, but similarly as calcium $(\mathrm{Ca})$, as a mobile element is may be leached, particularly in case of light soils, deeper into the soil profile by precipitation waters, which as a consequence contributes also to the consistent acidification of soil and poses a threat of insufficient nutrition of plants with this nutrient.

Sulfur is useful for the formation of amino acids, oligopeptides, chlorophyll, certain enzymes, vitamins and cofactors, proteins and oils, and a variety of secondary products in Allium (Leustek, 2002; Stewart, 2010). Sulfur containing secondary products are act as signaling molecules for fundamental cellular functions (Matsubayashi et al., 2002) and believed to take part in defense mechanisms against pathogenic organisms (Bell, 1981). Sulphur has been found to increase the bulb yield of onion and also improves its quality, especially pungency and flavour (Jaggi and Dixit, 1999). Severe sulphur deficiency during bulb development has detrimental effect on yield and quality of onion (Ajay and Singh, 1994). The original source of soil sulphur is metal sulphide minerals that when exposed to weathering, S-2 oxidizes to SO4-2 and uptake of sulfur into roots from the soil is almost exclusively as sulfate uptake (Havlin et al., 2005). Soils, which are deficient in sulphur, cannot on their own provide adequate sulphur to meet crop demand resulting in sulphur deficient crops and sub-optimal yields. Subsoil fertility also needs due consideration to have better prediction of sulphur supply in growing plants (Singh, 2001). It is possible to provide sulphur to plants through artificial nutrition. Incidental sulphur returns to soil is possible through farmyard manure and the use of conventional sulphur containing fertilizers, such as Ammonium sulphate $(24 \% \quad \mathrm{~S})$, Ammonium phosphate sulphate $(14 \% \mathrm{~S})$, Potassium sulphate (12\% S), Gypsum (17\% S) and Elemental sulphur (90-99\% S). The liquid fertilizers containing sulphur are Ammonium thiosulphate $(26 \% \mathrm{~S}), \quad$ Ammonium polysulphide $(40 \% \mathrm{~S})$, Potassium polysulphide $(22 \% \mathrm{~S})$ and Potassium thiosulphate $(17 \% \mathrm{~S})$ (Messick, 2014). Red and Laterite soils of 
West Bengal found deficient in sulphur ranged from 13 to 73 per cent with an average of 45.2 per cent. Among them, as per SAI (Sulphur Availability Index) 87 per cent of the surface soil samples of Birbhum district fall under low sulphur range (Patra et al., 2012).

Local farmers often grow onion as a cash crop and also to meet up household demand in Red and Laterite zone of West Bengal. However, inclusion of sulphur in crop nutrition programme was found rare. It was strongly felt that enriching the soil with sulphur fertilizer would be beneficial for onion crop of this region. An investigation was, therefore, conducted to study the effect of sulphur application on growth, productivity and quality of onion.

\section{Materials and Methods}

The present experiment was carried out during 2019-20 at Horticulture Farm of Department of Horticulture, SHUATS, Prayagraj. The experiment was conducted in Randomized Block Design (RBD), with 10+1 treatments, replicated thrice the treatments were $\mathrm{T}_{1}$ Control, $\mathrm{T}_{2}$ RDF (100\%), T 3 Sulphur @2\%, $\mathrm{T}_{4}$ Sulphur @4\%, $\mathrm{T}_{5}$ Sulphur @ 6\%, $\mathrm{T}_{6}$ Sulphur@8\%, $\mathrm{T}_{7}$ Magnesium@2\%, $\mathrm{T}_{8}$ Magnesium@4\%, T9 Magnesium@6\%, T 10 Magnesium@8\%.

\section{Climatic condition in the experimental site:}

The area of Prayagraj district comes under subtropical belt in the south east of Utter Pradesh, which experience extremely hot summer and fairly cold winter. The maximum temperature of the location reaches up to $46^{\circ}$ $\mathrm{C}-48^{\circ} \mathrm{C}$ and seldom falls as low as $4^{\circ} \mathrm{C}-5^{\circ} \mathrm{C}$. The relative humidity ranges between 20 to 94 $\%$. The average rainfall in this area is around $1013.4 \mathrm{~mm}$ annually. However, occasional precipitation is also not uncommon during winter months.

\section{Results and Discussion}

\section{Plant height at 30 DAS}

Data reveals that there was a significant effect of various treatment on plant height at 30 days after sowing (DAS). Among the different levels of Sulphur and Magnesium, $\mathrm{T}_{10}$ (Magnesium@ 8\%) recorded maximum plant height $23.77 \mathrm{~cm}$, followed by $\mathrm{T}_{5}$ (Sulphur@ $8 \%$ ) with $23.55 \mathrm{~cm}$, whereas minimum Plant height $20.47 \mathrm{~cm}$ was recorded in Control.

\section{Plant height at 60 DAS}

Data reveals that there was a significant effect of various treatments on plant height at 60 days after sowing (DAS) (Table 1).

Among the different levels of Sulphur and Magnesium $\mathrm{T}_{10}$ Magnesium@ 8\% recorded maximum plant height $47.54 \mathrm{~cm}$, followed by $\mathrm{T}_{6}$ (Sulphur @ 8\%) with $46.95 \mathrm{~cm}$, whereas minimum plant height $41.32 \mathrm{~cm}$ was recorded in Control.

\section{Plant height at 90 DAS}

Data reveals that there was a significant effect of various treatment on plant height at 90 days after sowing (DAS). Among the different levels of Sulphur and Magnesium $\mathrm{T}_{10}$ Magnesium@8\% recorded maximum plant height $68.51 \mathrm{~cm}$, followed by $\mathrm{T}_{6}$ (Sulphur @ $8 \%$ ) with $66.35 \mathrm{~cm}$, whereas minimum Plant height $59.70 \mathrm{~cm}$ was recorded in Control. Sulphur and Magnesium might be attributed to increase of leaf and ultimately leaf area per plant. More photosynthetic are might have resulted in more photosynthates manufacture and accumulation consequently more plant height. These findings are in agreement with those of Sirohi et al., (1992), Kumar et al., (1996), Islam et al., (1999), Singh et al., (2002), Kanton et al., (2002) and Aliyu et al., (2008). 


\section{Number of leaves}

\section{Number of leaves per plant at 30 DAS}

Data reveals that there was a significant effect of various treatments on Number of Leaves per plant at 30 days after sowing (DAS).

Among the different levels of Sulphur and Magnesium, $\mathrm{T}_{10}$ (Magnesium@ 8\%) recorded maximum Number of Leaves per plant $4.67 \mathrm{~cm}$, followed by $\mathrm{T}_{6}$ (Sulphur @ 8\%) with $4.47 \mathrm{~cm}$, whereas minimum Number of Leaves per plant $3.70 \mathrm{~cm}$ was recorded in Control.

\section{Number of leaves per plant at 60 DAS}

Data reveals that there was a significant effect of various treatments on Number of Leaves per plant at 60 days after sowing (DAS). Among the different levels of Sulphur and Magnesium T10 Magnesium@8\% recorded maximum Number of Leaves per plant $8.13 \mathrm{~cm}$, followed by $\mathrm{T}_{6}$ (Sulphur @ 8\%) with $7.93 \mathrm{~cm}$, whereas minimum Number of Leaves per plant $6.67 \mathrm{~cm}$ was recorded in Control.

\section{Number of leaves per plant at 90 DAS}

Data reveals that there was a significant effect of various treatments on Number of Leaves per plant at 90 days after sowing (DAS).

Among the different levels of Sulphur and Magnesium T10 Magnesium@8\% recorded maximum Number of Leaves per plant 10.87 $\mathrm{cm}$, followed by $\mathrm{T}_{6}$ (Sulphur @ 8\%) with $10.27 \mathrm{~cm}$, whereas minimum Number of Leaves per plant $8.53 \mathrm{~cm}$ was recorded in Control.

Application of Sulphur and Magnesium increased the Number of Leaves per plant. the initiation of more number of leaves in the plant. Similar findings have been reported by Yadav et al., (2003), Haque et al., (2004),
Joshi et al., (2005) and El- Tantawy and ElBeik (2009).

\section{Fresh weight of the bulb}

Among the different levels of Sulphur and Magnesium $\mathrm{T}_{10}$ (Magnesium@ 8\%) recorded maximum Fresh weight of bulb per plant 70.60, followed by $\mathrm{T}_{6}$ (Sulphur @ 8\%) with 70.32, whereas minimum Fresh weight of bulb per plant 50.75 days was recorded in control.

The plants grown under wider spacing received more nutrients, light and moisture around compared to plants of closer spacing, which was probably the cause of better performance in yield attributes and yield of individual.

Singh et al., (2002), Kanton et al., (2002), Khan et al., (2003), Naik and Hosamani (2003), Viloria et al., (2003), Aliyu et al., (2008) and Dubey et al., (2011) also found similar results.

\section{Neck thickness}

The Neck thickness was significantly found to be influenced by Sulphur and Magnesium. The maximum Neck thickness was found in $\mathrm{T}_{10}$ (Magnesium@8\%) which was $13.25 \mathrm{~mm}$ and the minimum Neck thickness were obtained in $\mathrm{T}_{1}$ (control) which was $8.74 \mathrm{~mm}$.

The above findings shows optimum The plants grown under wider spacing received more nutrients, light and moisture around compared to plants of closer spacing, which was probably the cause of better performance in yield attributes and yield of individual.

Singh et al., (2002), Kanton et al., (2002), Khan et al., (2003), Naik and Hosamani (2003), Viloria et al., (2003), Aliyu et al., (2008) and Dubey et al., (2011) also found similar results. 
Table.1 Effect of different levels of Sulphur and Magnesium on different parameter of the Onion (Allium Cepa.)

\begin{tabular}{|c|c|c|c|c|c|c|c|c|c|c|c|c|c|}
\hline \multirow[t]{2}{*}{ Treatment } & \multirow{2}{*}{$\begin{array}{l}\text { Treatment } \\
\text { Combination }\end{array}$} & \multicolumn{3}{|c|}{ Plant height } & \multicolumn{3}{|c|}{ Number of Leaves } & \multirow{2}{*}{$\begin{array}{l}\text { Fresh } \\
\text { weight of } \\
\text { bulb }\end{array}$} & \multirow{2}{*}{$\begin{array}{c}\text { Neck } \\
\text { Thickness }\end{array}$} & \multirow{2}{*}{$\begin{array}{l}\text { Equatorial } \\
\text { Diametr }\end{array}$} & \multirow{2}{*}{$\begin{array}{l}\text { Polar } \\
\text { Diameter }\end{array}$} & \multirow{2}{*}{$\begin{array}{l}\text { Bulb } \\
\text { Yield }\end{array}$} & \multirow[t]{2}{*}{ T.S.S. } \\
\hline & & $\begin{array}{c}30 \\
\text { DAS }\end{array}$ & $\begin{array}{c}60 \\
\text { DAS }\end{array}$ & $\begin{array}{c}90 \\
\text { DAS }\end{array}$ & $\begin{array}{c}30 \\
\text { DAS }\end{array}$ & $\begin{array}{c}60 \\
\text { DAS }\end{array}$ & $\begin{array}{c}90 \\
\text { DAS }\end{array}$ & & & & & & \\
\hline $\mathbf{T}_{1}$ & Control & 20.47 & 41.32 & 59.70 & 3.70 & 6.67 & 8.53 & 50.75 & 8.74 & 5.22 & 4.64 & 175.86 & 7.74 \\
\hline $\mathbf{T}_{2}$ & RDF $(100 \%)$ & 21.01 & 42.46 & 61.10 & 3.87 & 7.10 & 8.73 & 57.15 & 9.46 & 5.35 & 4.68 & 177.28 & 8.54 \\
\hline $\mathbf{T}_{\mathbf{3}}$ & Sulphur@2\% & 21.09 & 42.66 & 61.40 & 4.10 & 7.34 & 8.83 & 61.54 & 9.76 & 5.61 & 4.74 & 182.16 & 8.78 \\
\hline $\mathbf{T}_{4}$ & Sulphur@4\% & 21.39 & 41.90 & 61.50 & 3.97 & 6.83 & 9.87 & 64.15 & 10.17 & 5.73 & 4.88 & 189.78 & 9.22 \\
\hline $\mathbf{T}_{5}$ & Sulphur@6\% & 21.81 & 42.95 & 62.40 & 4.20 & 7.43 & 9.13 & 67.53 & 10.90 & 5.87 & 4.91 & 191.50 & 9.78 \\
\hline $\mathbf{T}_{6}$ & Sulphur@8\% & 23.55 & 46.95 & 66.35 & 4.47 & 7.57 & 10.27 & 70.32 & 12.57 & 5.90 & 5.10 & 206.45 & 10.29 \\
\hline $\mathbf{T}_{7}$ & Magnesium@2\% & 22.95 & 44.83 & 64.34 & 4.03 & 7.23 & 10.00 & 68.48 & 11.26 & 5.43 & 4.81 & 183.70 & 8.83 \\
\hline $\mathbf{T}_{8}$ & Magnesium@4\% & 22.52 & 45.04 & 65.15 & 4.40 & 7.93 & 9.97 & 69.55 & 12.57 & 5.51 & 4.97 & 193.25 & 8.97 \\
\hline $\mathbf{T}_{9}$ & Magnesium@6\% & 22.65 & 46.27 & 66.25 & 4.27 & 7.53 & 10.07 & 68.45 & 11.85 & 5.88 & 5.05 & 199.45 & 9.72 \\
\hline \multirow[t]{3}{*}{$\mathbf{T}_{10}$} & Magnesium@8\% & 23.77 & 47.54 & 68.51 & 4.67 & 8.13 & 10.87 & 70.60 & 13.25 & 5.97 & 5.23 & 213.35 & 10.70 \\
\hline & S.Ed. ( \pm$)$ & 2.11 & 1.24 & 0.49 & 0.97 & 0.24 & 0.54 & 1.56 & 0.25 & 0.252 & 0.34 & 2.81 & 0.07 \\
\hline & C.D. At $5 \%$ & 4.21 & 2.53 & 1.02 & 1.91 & 0.52 & 1.18 & 3.21 & 0.63 & 0.512 & 0.78 & 5.95 & 0.15 \\
\hline
\end{tabular}




\section{Equatorial diameter of bulb $(\mathrm{cm})$}

The effect of Sulphur and Magnesium on Equatorial diameter of bulb of Onion was found significant and varied among the treatments. The highest yield was found in $\mathrm{T}_{10}$ (Magnesium@ 8\%) which was $5.97 \mathrm{~cm}$ ha ${ }^{1}$ and the lowest yield were obtained in $\mathrm{T}_{1}$ (control) which was $5.22 \mathrm{~cm}$.

Equatorial diameter of bulb which was probably the cause of better performance in yield attributes and yields of individual. Singh et al., (2002), Kanton et al., (2002), Khan et al., (2003), Naik and Hosamani (2003), Viloria et al., (2003), Aliyu et al., (2008) and Dubey et al., (2011) also found similar results.

\section{Polar diameter of the bulb}

The Polar diameter of bulb weight was significantly found to be influenced by Sulphur and Magnesium among the treatments. The maximum Polar diameter of bulb $\mathrm{cm}$ was found in $\mathrm{T}_{10}$ (Magnesium@ $@$ \%) which was $5.23 \mathrm{~cm}$ and the minimum Polar diameter of bulb was obtained at $\mathrm{T}_{1}$ (control) which was $4.64 \mathrm{q} \mathrm{ha}^{-1}$. which was probably the cause of better performance in yield attributes and yield of individual. Singh et al., (2002), Kanton et al., (2002), Khan et al., (2003), Naik and Hosamani (2003), Viloria et al., (2003), Aliyu et al., (2008) and Dubey et al., (2011) also found similar results.

\section{Bulb yield}

The result of the data shows that the Bulb yield was found to be significant by Sulphur and Magnesium For post harvest the maximum Bulb yield $213.35 \mathrm{q} \mathrm{ha}^{-1}$ at $\mathrm{T}_{10}$ (Magnesium@8\%) and minimum Bulb yield was $175.86 \mathrm{q} \mathrm{ha}^{-1}$ at $\mathrm{T}_{6}$ (Sulphur@8\%) and was found to be significant. The above observation shows that increasing which was probably the cause of better performance in yield attributes and yield of individual. Singh et al., (2002), Kanton et al., (2002), Khan et al., (2003), Naik and Hosamani (2003), Viloria et al., (2003), Aliyu et al., (2008) and Dubey et al., (2011) also found similar results.

\section{Total Soluble Solids}

The result of the data shows that the Total soluble solid ( ${ }^{\circ}$ Brix) was found to be significant by Sulphur and Magnesium For post harvest the maximum Total soluble solid ( ${ }^{\circ}$ Brix) 10.70 at $\mathrm{T}_{10}$ (Magnesium@ 8\%) and minimum Total soluble solid ( ${ }^{\circ}$ Brix) was 7.74 at $\mathrm{T}_{6}$ (Sulphur @8\%) and was found to be significant.

Application of Magnesium had significant influence on total soluble solids. Each incremental dose of Magnesium cause significant increase in total soluble solid. Highest total soluble solids content was determined with application of Sulphur and Magnesium. The application of Magnesium might have enhanced the availability of minerals and accumulation of soluble solids in onion bulbs which resulted in more total soluble solid. Banafer and Gupta (2005) also found that total soluble solid content in bulb were increased with the application of different levels of Magnesium.

It is concluded from the present study that application of Sulphur and magnesium at @2\%,@4\%,@6\% and @8\% along with $100 \% \mathrm{~N}, \mathrm{P}, \mathrm{K}$ produced the higher yield of onion, but also improved the soil fertility as compared to application of chemical fertilizers alone. The complimentary use of micronutrients is advantageous as it helps increase $\mathrm{N}, \mathrm{P}$ and $\mathrm{K}$ uptake, maintain micronutrients levels in soil and increases crop productivity. Thus, optimum mineral nutrition along with micronutrient can result in high yield potential of onion through its favorable effect on nutrient supply and soil properties. 


\section{References}

Aliyu, U., Dikko, A.U., Magaji, M.D. and A. Singh (2008). Nitrogen and intra row spacing effects on growth and yield of onion (Allium cepa L.). Journal of Plant Science, 3(3): 188-193.

Arkery, H.R., Chalam, G.V., Satyanaryana, P. and Dona-hue, R.L.(1956).Soil management in India, Asian Pub. House, Bombay.

Awurum, A.N. (2001). Effect of population density on the growth and yield of onion in Umudike, South Eastern Nigeria. Journal of Sustainable Agriculture and the Environment, 3 (2): 337-340.

Dhital, M., Dutta, J.P., Shakya, S.M. and Sharma, M.D. (2015). Effect of different levels of nitrogen on commercial onion varities for off season green production in western chitwan, Nepal. International Journal of Research (IJR).

Dubey, B.K., Mishra, R., Bhonde, S.R. and Gupta, R.P. (2011) Standardization of planting time and spacing in hybrid onion variety 'Colina'e for export quality bulb production during late kharif. In Souvenir and abstract National symposium on Alliums current scenario and emerging Trends (pp. 205- 206).

Godara, A.S. and Mehta, R.S., (2013) Response of onion (Allium cepa L.) to crop geometry and nitrogen levels on growth and yield of kharif onion. Progressive Horticulture Vol 45 No 1 pp. 214-217.

Grubben, J.H. and D.A. Denton. 2004. Plant resources of tropical Africa. PROTA
Foundation, Wageningen; Back huys, Leiden; CTA, Wageningen

Haque, M. I., Zaman, M. M., Hasan, M. K., Mahfuza, Begum and F. Pervin (2004). Growth and yield of onion as influenced by nitrogen and irrigation. Journal of Agriculture and Rural Development, 2(1): pp 151- 153.

Hemla, Naik, B.H. and Hosamani, R.M. (2003). Study of spacing and different level of nitrogen on growth and yield of kharif onion (Allium cepa L.)-Approaches for sustainable development on onion and garlic, pp.(181-184)

Kumar, S., Tiwari, C.P. and Vinay Singh (2006). Bulb yield and quality of onion (Allium cepa L.) as affected by application rates of nitrogen and potassium fertilizer. Agriculture Science Digest, 26 (1): pp 11-14.

Lannoy, G. De. 2001. Vegetable Crops in Tropical Africa 395-511. In: Raemaeks R. H. (Editor). Crop Production in Tropical Africa. 1540 pp. Directorate General for International Cooperation (DGIC) Belgium. Malik, M. N., 2000. Horticulture. Biotech Books. Delhi. 586p.

Nasreen, S., Haque, M.M., Hossain, M.A. and A.T.M. Farid (2007). Nutrient uptake and yield of onion as influenced by nitrogen and sulphur fertilization. Bangladesh Journal of Agricultural Research, 32(3): pp $413-420$.

Singh, Ram Batuk and S. B. Singh (2000). Significance of nitrogen, phosphorus and potassium on onion (Allium cepa L.) raised from onion sets (bulblets). Vegetable Science, 27(1): pp 88-89.

\section{How to cite this article:}

Dubey Bhashkar and Singh Devi. 2021. Effect of Different Levels of Sulphur and Magnesium on Growth, Yield and Quality of Onion. Int.J.Curr.Microbiol.App.Sci. 10(02): 3112-3118. doi: https://doi.org/10.20546/ijcmas.2021.1002.340 